\title{
SYNTHESIS AND PLANT GROWTH ACTIVITY OF 2-(4-OXOCHROMEN-3-YL)BENZOTHIAZOLIUM AND - BENZOXAZOLIUM BROMIDES
}

\author{
MÁRIA HENSELOVÁ ${ }^{1}$, RENATA GAŠPAROVÁ \\ MARGITA LÁCOVÁ ${ }^{3}$ \\ ${ }^{1}$ Department of Plant Physiology, Faculty of Natural Sciences, Comenius University, \\ Mlynská dolina B-2, SK-842 15 Bratislava, Slovak Republic \\ ${ }^{2}$ Department of Chemistry, Faculty of Natural Sciences, University of SS. Cyril and \\ Methodius, Námestie Jozefa Herdu 2, SK-917 01 Trnava, Slovak Republic \\ ${ }^{3}$ Department of Organic Chemistry, Faculty of Natural Sciences, Comenius University, \\ Mlynská dolina CH-2, SK-842 15 Bratislava, Slovak Republic
}

\begin{abstract}
A facile synthesis of novel 2-(4-oxochromen-3-yl) benzothiazolium bromides 4 and benzoxazolium bromide 5 using the one-pot condensation of substituted 4-oxochromene-3-carboxaldehydes 1 with 2-methylbenzothiazole (2a) or 2-methylbenzoxazole (2b) and benzyl bromide is described. The effects of benzothiazolium bromides $\mathbf{4}$ on the growth stimulation of the cucumber and retardant activity on corn seedlings were investigated. They inhibited growth of cucumber (root and hypocotyl) and shoots of corn at the range of $10-100 \mathrm{ppm}$ and stimulated at $0.1-1 \mathrm{ppm}$ concentrations.
\end{abstract}

Keywords: plant growth activity, benzothiazolium, benzoxazolium salts, 4-oxochromene-3-carboxaldehydes

\section{Introduction}

Benzothiazole derivatives represent a large group of heterocyclic substances, which were tested for a different biological activity (SUTORIS et al., 1988; KRÁLOVÁ et al., 1994; EL-SHAAER et al., 1998). 2-R substituted benzotiazole derivatives manifested antibacterial and antifungal activities (AFSAH and NAYER 1996; MAGDOLEN et al., 2000; BUFFA et al., 2001) and are reported also to be active as antineoplastics agent (KRIEG and BILLITZ 1996). According ŠIMONOVÁ et al., (2005) ones were characterized as biologically active substances with dominant auxin-like growth promoting activity. 3-R substituted benzothiazole derivatives influenced the prolongation of growth, stimulated the plant regeneration, activity of peroxidase, and may induce the dedifferentiation and morphogenesis of plants in in vitro conditions (SUTORIS et al., 1993; HAVEL et al., 1994). Benzothiazole derivatives were also observed as protective agents against UV-induced mutagenesis in Euglena gracilis FOLTÍNOVÁ et al., (2003) and also against of cadmium stress HENSELOVÁ et al., (2007); KLECOVÁ - ŠIMONOVÁ et al. (2008) in Phytollaca dioica, Vigna radiata and Brassica juncea plants.

A large number of 4-oxochromene derivatives occur in nature and exhibit variety of biological activities, e.g. antialgal (KRÁLOVÁ et al., 1998), antifungal, antimycobacterial and antiparasitic (CAUJOLLE et al., 1993; LÁCOVÁ et al., 1995; GAŠPAROVÁ et al., 1997; NAWROT-MODRANKA et al., 2006), however, none of 
them have been reported to have plant growth regulation activity. This paper described the auxin and retardant-like growth activity of newly synthesized oxochromene benzothiazole compounds.

\section{Materials and methods}

\subsection{Chemistry}

Scheme 1 shows the synthetic pathway to benzothiazolium and benzoxazolium salts. More synthetic details as well as the characteristic data of synthesized compounds are described (KLEŠTINEC et al., 2008).

General procedure for synthesis $4 a-5$

A stirred mixture of 4-oxochromene-3-carboxaldehyde 1a (1 mmol), 2methylbenzothiazole 2a (1 mmol) (or 2-methyloxazole $2 \mathbf{b}$ ) and benzylbromide (1 mmol) in anhydrous nitromethane $\left(2 \mathrm{dm}^{3}\right)$ was irradiated in microwave oven at $270 \mathrm{~W}$ for $10 \mathrm{~min}$. After cooling, the solid product was filtered off, washed with warm acetone and crystallized from acetonitrile to give $45-81 \%$ yields of products.

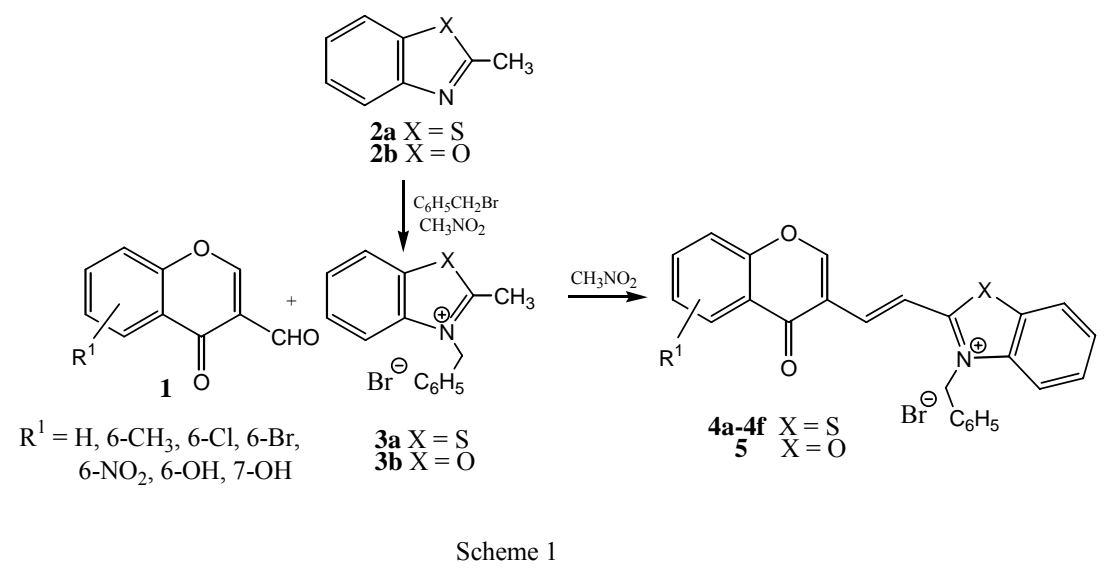

\subsection{Study of the Plant Growth Activity}

The solutions of salts $\mathbf{4}$ - $\mathbf{5}$ were prepared in dimethylsulfoxide (DMSO). The final concentration of DMSO in experiments, including the control, was held constant at $1 \%$ by volume. This concentration of DMSO had no detectable effect on the growth of plants under experimental conditions. For determination of stimulated growth activitylike indole-3-acetic acid (IAA) we used the bioassay as described by MERRILL (1989) in this modification: Twenty seeds of cucumber (Cucumis sativus L. cv. Regina) were placed in $12 \mathrm{~cm}$ Petri-dishes on two layers of filter paper Whatman № 2, wetted with $15 \mathrm{ml}$ of distilled water (control), or of the indicated benzothiazole 
solution at $0.1,1$ and $10 \mathrm{ppm}$ concentrations. The Petri-dishes were placed to a dark box and incubated at $28{ }^{\circ} \mathrm{C}$. The length of the root and hypocotyl seedlings was measured to the nearest milimeter after 7 days. The stimulated effect of tested compounds was evaluated and compared with the control and standard IAA in the range from 0.001 to $10 \mathrm{ppm}$ concentrations. For corn bioassay in nutrient culture the seeds of corn (Zea mays L. cv. Greta) were pregerminated by soaking them in water for 24 hours. Twenty-five seeds were placed on wet filter paper in the Petri-dishes of $20 \mathrm{~cm}$ diameter for 48 hours at $25^{\circ} \mathrm{C}$ to the dark box. Seeds selected for treatment had a coleoptile emergence of 10 to $15 \mathrm{~mm}$. For determination of retardant activity-like abscisic acid (ABA) we used the seedlings bioassay as described by DATHE et al., (1978): Twenty seedlings were chosen per every variant and placed after two seedlings in glass flasks containing $4 \mathrm{ml}$ of half nutrient solution prepared according BROWN and DALTON (1970) with application of testing compounds in 1, 10 and $100 \mathrm{ppm}$ concentrations. The treated and untreated corn plants were cultivated under glass cover in climatic box (temperature $25 / 15^{\circ} \mathrm{C}$ during 16 hours photoperiod and light intensity of $60 \mu \mathrm{mol} \cdot \mathrm{m}^{-2} \cdot \mathrm{s}^{-1}$ with a relative humidity of $\left.80 \%\right)$. The level of the solutions in the flasks was maintained daily by adding nutrient solution. The length of the corn shoots was measured after 7 days and compared with the control and standard ABA. The standards IAA and ABA come from Sigma, St. Louis, MO, USA. All dates are presented as arithmetic averages of the individual experiments. Bioassay results were statistically evaluated using the Student's $t$-test.

\section{Results and discussion}

\subsection{Study of inhibition of germination and early growth of cucumber and corn seedlings}

It is obvious from our experimental data that the biological growth effects depend on concentrations of tested compounds. The cucumber growth test and corn bioassay have been used as a specific and sensitive tests for verification of auxin and retardant activities of tested benzothiazole compounds. The differences in auxin (IAA) and retardant (ABA) like growth activities between tested derivatives are evident from Tables 1 and 2. In general, the inhibition activity was observed at higher (10-100 $\mathrm{ppm})$, and the stimulation activity at lower (0.1-1 ppm) concentrations. All tested compounds showed concentration-dependent stimulation activity in growth elongation of cucumber hypocotyl and root (Table 1). Growth elongation of hypocotyls was increased from $6 \%$ (compound No.5) to $42 \%$ (No. 4a). In the case of root growth, maximum stimulation was achieved following the application of $0.1 \mathrm{ppm}$ concentration from $14.3 \%$ (No. $4 \mathrm{e}$ ) to $45 \%$ (No. $4 \mathrm{c}$ ). Their effects were similar not only to those of synthetic auxin IAA, but also 2,4-dichlorophenoxyacetic acid (YORK et al., 1984; SUTORIS et al., 1993) which stimulated elongation of pea stem and wheat coleoptile segments. The highest significant growth stimulation was achieved following application-tested substances in a concentration range of 0.1 to $1 \mathrm{ppm}$ for both hypocotyl and root. Compounds No. $4 \mathrm{~b}$ and 5 have no stimulation effect on root growth (Table 1). However, all the compounds were weaker, than IAA, which 
exhibited maximum effect $(61-65 \%)$ at a concentration one hundred times lower (0.001 ppm). Similar effects achieved SUTORIS et al., (1993) at testing of 3phenoxycarbonyl-methyl- and 3-aryloxycarbonyl-methyl-2-benzothiazolinones and (ŠIMONOVÁ et al., (2005) at 2-R substituted benzothiazole derivatives. In the range of $10^{-3}-10^{-7} \mathrm{M}$ concentrations the compounds showed different auxin-like effects on elongation growth of wheat coleoptile segments and the formation and number of adventitious roots and the length of hypocotyl in mung bean.

Tab. 1. Effect of 4a-5 benzothiazole compounds and indole-3-acetic acid (IAA) on root and hypocotyl length in cucumber cv. Regina.

\begin{tabular}{|c|c|c|c|c|c|}
\hline \multirow[t]{2}{*}{$\begin{array}{c}\text { Compound } \\
\mathbf{R}^{1}\end{array}$} & \multirow[t]{2}{*}{$\begin{array}{c}\text { Concentration } \\
{[\mathrm{ppm}]}\end{array}$} & \multicolumn{2}{|c|}{$\begin{array}{c}\text { Mean length } \\
{[\mathrm{mm}]}\end{array}$} & \multicolumn{2}{|c|}{ \% of control } \\
\hline & & Root & Hypocotyl & Root & Hypocotyl \\
\hline control & - & 63.5 & 36.6 & 100.0 & 100.0 \\
\hline \multirow{3}{*}{$\begin{array}{c}\mathbf{4 a} \\
\mathrm{H}\end{array}$} & 0.1 & 83.0 & 52.0 & $130.7^{\mathrm{a}}$ & $142.1^{\mathrm{a}}$ \\
\hline & 1.0 & 77.0 & 48.5 & $121.2^{\mathrm{a}}$ & $132.5^{\mathrm{a}}$ \\
\hline & 10.0 & 63.0 & 44.7 & 99.2 & 122.1 \\
\hline \multirow{3}{*}{$\underset{6-\mathrm{CH}_{3}}{\mathbf{4 b}}$} & 0.1 & 59.0 & 44.7 & 92.9 & $122.1^{\mathrm{a}}$ \\
\hline & 1.0 & 52.2 & 38.2 & $82.2^{\mathrm{a}}$ & 104.4 \\
\hline & 10.0 & 40.0 & 26.2 & $63.0^{\mathrm{a}}$ & $71.6^{\mathrm{a}}$ \\
\hline \multirow{3}{*}{$\begin{array}{c}4 c \\
6-\mathrm{Cl}\end{array}$} & 0.1 & 92.0 & 46.2 & $144.9^{\mathrm{a}}$ & $126.2^{\mathrm{a}}$ \\
\hline & 1.0 & 71.8 & 39.8 & $113.1^{\mathrm{b}}$ & 108.7 \\
\hline & 10.0 & 45.8 & 26.8 & $72.1^{\mathrm{a}}$ & $73.2^{\mathrm{a}}$ \\
\hline \multirow{3}{*}{$\begin{array}{c}\text { 4d } \\
6-\mathrm{Br}\end{array}$} & 0.1 & 80.0 & 50.5 & $126.0^{\mathrm{a}}$ & $137.9^{\mathrm{a}}$ \\
\hline & 1.0 & 63.0 & 47.0 & 99.2 & $128.4^{\mathrm{a}}$ \\
\hline & 10.0 & 61.0 & 10.7 & 96.1 & $111.2^{b}$ \\
\hline \multirow{3}{*}{$\begin{array}{c}\mathbf{4 e} \\
6-\mathrm{NO}_{2}\end{array}$} & 0.1 & 72.6 & 47.0 & $114.3^{b}$ & $128.4^{\mathrm{a}}$ \\
\hline & 1.0 & 51.8 & 44.2 & $81.6^{\mathrm{a}}$ & $120.8^{\mathrm{a}}$ \\
\hline & 10.0 & 48.6 & 35.2 & $76.5^{\mathrm{a}}$ & 96.2 \\
\hline \multirow{3}{*}{$\begin{array}{c}\mathbf{4 f} \\
6-\mathrm{OH}\end{array}$} & 0.1 & 89.7 & 49.2 & $141.2^{\mathrm{a}}$ & $134.4^{\mathrm{a}}$ \\
\hline & 1.0 & 79.7 & 47.5 & $125.5^{\mathrm{a}}$ & $129.8^{\mathrm{a}}$ \\
\hline & 10.0 & 64.0 & 43.2 & 100.8 & $118.0^{\mathrm{a}}$ \\
\hline \multirow{3}{*}{$\begin{array}{c}\mathbf{4 g} \\
7-\mathrm{OH}\end{array}$} & 0.1 & 74.6 & 41.2 & $117.5^{b}$ & $112.6^{\mathrm{a}}$ \\
\hline & 1.0 & 70.4 & 35.8 & $110.9^{b}$ & 97.8 \\
\hline & 10.0 & 48.8 & 33.7 & $76.8^{b}$ & 92.1 \\
\hline \multirow{3}{*}{$\stackrel{5}{6}-\mathrm{CH}_{3}$} & 0.1 & 61.2 & 38.8 & 96.4 & 106.0 \\
\hline & 1.0 & 39.0 & 25.4 & $61.4^{\mathrm{a}}$ & $69.4^{\mathrm{a}}$ \\
\hline & 10.0 & 31.2 & 19.2 & $49.1^{\mathrm{a}}$ & $52.4^{\mathrm{a}}$ \\
\hline \multirow{5}{*}{$\begin{array}{c}\text { IAA } \\
\text { standard }\end{array}$} & 0.001 & 104.8 & 58.9 & $165.0^{\mathrm{a}}$ & $160.9^{\mathrm{a}}$ \\
\hline & 0.01 & 94.8 & 51.2 & $149.3^{\mathrm{a}}$ & $139.9^{\mathrm{a}}$ \\
\hline & 0.1 & 86.4 & 44.6 & $136.1^{\mathrm{a}}$ & $121.8^{\mathrm{a}}$ \\
\hline & 1.0 & 79.8 & 43.1 & $125.7^{\mathrm{a}}$ & $117.7^{\mathrm{a}}$ \\
\hline & 10.0 & 32.2 & 27.9 & $50.7^{\mathrm{a}}$ & $76.2^{\mathrm{a}}$ \\
\hline
\end{tabular}

| ${ }^{\mathrm{a}}$ Values are significantly different at the $1 \% ;{ }^{b}$-values are significantly different at the $5 \%$ level against the control as determined by Student's $t$-test.

Present studies thus show that the compounds retarded shoot growth of corn, although not necessarily at the same rate (Table 2). The majority of tested compounds showed retardation activity in elongation shoot growth of corn seedlings in the range 
of $10-100 \mathrm{ppm}$ concentrations. This effect, in dependence on the compound structure, amounted up to $82 \%$ at No.5 (Table 2). At the highest concentration (100 ppm) the compounds exhibited a morfogenic effect evident in the dwarfing of corn coleoptile and cucumber hypocotyle. It is known that the synthetic auxins at higher concentrations causes inhibition of growth, stem twisting, and other formative effects in susceptible plants (CHANG and FOY 1983; FARGAŠOVÁ 1994). On the other hand however, stimulates both root and shoot growth of many plants at rates lower, what confirmed also our results. The effect of tested substances was comparable with that of ABA (Table 2) with exception of compounds No. $4 \mathrm{~b}$ and 5 that exhibited higher retardant activity $(63-82 \%)$ in compare to the standard $(42.8 \%)$ at the same concentration of $100 \mathrm{ppm}$. Three compounds (4a, 4e and 4f) had no retardant effect on corn shoot growth in the range of tested concentrations (Table. 2).

Tab. 2. Effect of $4 a-5$ benzothiazole compounds and abscisic acid (ABA) on shoot length of corn cv. Greta.

\begin{tabular}{|c|c|c|c|}
\hline Compound & $\begin{array}{l}\text { Concentration } \\
(\mathrm{ppm})\end{array}$ & $\begin{array}{l}\text { Mean length of the shoot } \\
(\mathrm{mm})\end{array}$ & $\%$ of control \\
\hline control & - & 121.4 & 100.0 \\
\hline $4 a$ & $\begin{array}{c}1 \\
10 \\
100 \\
\end{array}$ & $\begin{array}{l}155.5 \\
143.0 \\
142.0\end{array}$ & $\begin{array}{l}128.1^{\mathrm{a}} \\
117.8^{\mathrm{a}} \\
116.9^{\mathrm{a}}\end{array}$ \\
\hline $4 b$ & $\begin{array}{c}1 \\
10 \\
100\end{array}$ & $\begin{array}{c}113.0 \\
65.0 \\
45.0\end{array}$ & $\begin{array}{c}93.1 \\
53.5^{\mathrm{a}} \\
37.1^{\mathrm{a}}\end{array}$ \\
\hline $4 c$ & $\begin{array}{c}1 \\
10 \\
100\end{array}$ & $\begin{array}{c}185.0 \\
141.0 \\
98.5\end{array}$ & $\begin{array}{c}152.4^{\mathrm{a}} \\
116.1^{\mathrm{a}} \\
81.1^{\mathrm{a}}\end{array}$ \\
\hline 4d & $\begin{array}{c}1 \\
10 \\
100 \\
\end{array}$ & $\begin{array}{c}125.0 \\
142.0 \\
93.0\end{array}$ & $\begin{array}{c}102.9 \\
116.9^{\mathrm{a}} \\
76.6^{\mathrm{a}}\end{array}$ \\
\hline $4 e$ & $\begin{array}{c}1 \\
10 \\
100\end{array}$ & $\begin{array}{l}135.0 \\
145.0 \\
121.5\end{array}$ & $\begin{array}{c}111.2^{\mathrm{b}} \\
119.4^{\mathrm{a}} \\
100.1\end{array}$ \\
\hline $4 f$ & $\begin{array}{c}1 \\
10 \\
100\end{array}$ & $\begin{array}{l}132.0 \\
146.0 \\
143.5\end{array}$ & $\begin{array}{c}108.7 \\
120.3^{\mathrm{a}} \\
118.2^{\mathrm{a}}\end{array}$ \\
\hline 5 & $\begin{array}{c}1 \\
10 \\
100\end{array}$ & $\begin{array}{c}126.0 \\
101.0 \\
22.0\end{array}$ & $\begin{array}{l}103.8 \\
83.2^{\mathrm{a}} \\
18.1^{\mathrm{a}}\end{array}$ \\
\hline $\begin{array}{c}\text { ABA } \\
\text { standard }\end{array}$ & $\begin{array}{c}1 \\
10 \\
100\end{array}$ & $\begin{array}{l}95.4 \\
77.4 \\
45.2\end{array}$ & $\begin{array}{l}78.6^{\mathrm{a}} \\
63.7^{\mathrm{a}} \\
572^{\mathrm{a}}\end{array}$ \\
\hline
\end{tabular}

The enhancement of growth of cucumber and corn seedlings at the lower concentrations and, on the other hand, their inhibition effect at higher concentrations 
observed in tested of benzothiazole derivatives are according to MERRILL'S characteristic growth pattern for auxins. Auxins generally showed the best induction of adventitious roots and stimulated the elongation growth on various plants (MÜLLER 2000; WANG et al., 2003; KOLLÁROVÁ et al., 2005). Mode(s) of action of growth stimulators, especially auxin-like substances as were tested compounds, have often been hypothesized as being involved in the regulation of synthesis or degradation of endogenous auxin indole-3-acetic acid (IAA) in plants (DAVIES 1995).

\section{Conclusions}

The effects of 3-Benzyl-2-[(6-R-4-oxochromen-3-yl)ethenyl]benzothiazolium bromides $\mathbf{4 a}-\mathbf{4 g}$ and 3-Benzyl-2-[(6-R-4-oxochromen-3-yl)ethenyl]benzoxazolium bromide and 5 were tested on the germination and early growth of cucumber and corn seedlings. The tested oxochromene benzothiazole derivatives may be characterized as biologically active substances with auxin and retardant growth promoting activity. They inhibited growth of cucumber (root and hypocotyl) and shoots of corn at the range of $10-100 \mathrm{ppm}$ and stimulated at $0.1-1 \mathrm{ppm}$ concentrations. The most effective compounds with stimulating activity on cucumber seedlings was $4 a(R=H)$, 4f $(\mathrm{R}=\mathrm{OH})$ and the best retardant activity on corn seedlings showed $\mathbf{5}\left(\mathrm{R}=\mathrm{CH}_{3}\right)$ and 4b $\left(\mathrm{R}=\mathrm{CH}_{3}\right)$.

Acknowledgement: The authors are grateful for financial support to the Slovak Research and Development Agency by way of project No. APVT-20-005204 and to the VEGA Grant Agency of Slovak Ministry of Education by way of project No. 1/3584/06.

\section{References}

AFSAH, S.A., NAYER, S.A.: Synthesis of some styryl chain substituted benzothiazolium asymmetric cyanines: Spectra and antimicrobial studies. Asian J. Chem., 8, 1996, 419-424.

BROWN, B.T., DALTON, L.K.: Morphactin-like activity of benzilate esters in Arabidopsis thaliana.“ In: D.J. CARR (Ed.), Plant Growth Substances. SpringerVerlag, Berlin-Heidelberg-New York. 1970, 318-323.

BUFFA, R., ZAHRADNÍK, P., FOLTÍNOVÁ, P.: Computer aided benzothiazole derivativess. synthesis, structure and biological study of new push-pull conjugated benzothiazolium salts. Heterocyclic Commun., 7, 2001, 331-336.

CAUJOLlE, R., BAZIARD-MOUYSSET, G., FAVROT, J. D., PAYARD, M., LOISEAU, P. R., AMAROUCH, H., LINAS, M. D., SEGUELA, J. P., LOISEAU, P. M.: Synthesis, antiparasitic and antifungal activities of arylalkyl and arylvinylthiazolines. Eur. J. Med. Chem., 28, 1993, 29 - 35.

DATHE, W., SCHNEIDER, G., SEMBDNER, G.: Endogenous gibberellins and inhibitors in caryopses of rye. Phytochemistry, 17, 1978, 963-966.

DAVIES, P.J.: Plant hormones, physiology, biochemistry and molecular biology. Kluwer Academic Publishers, Dordrecht-Boston-London 1995, 833 p.

EL-SHAAER, H.M., FOLTÍNOVÁ, P., LÁCOVÁ, M., CHOVANCOVÁ, J., STANKOVIČOVÁ, H.: Synthesis, antimicrobial activity and bleaching effect of 
some reaction products of 4-oxo-4H-benzopyran-3-carboxaldehydes with aminobenzothiazoles and hydrazides. Il Farmaco, 53, 1998, 224-232.

FARGAŠOVÁ, A.: Toxicity determination of selected plant growth hormones on germination and root growth of Sinapis alba seeds. Biologia (Bratislava), 49, 1994, 109-112.

FOLTÍNOVÁ, P., MAGDOLEN, P. ZAHRADNÍK, P.: Inhibition of UV-induced mutagenesis in Euglena gracilis by benzothiazole derivatives. Pharmazie, 58, 2003, 4.

GAŠPAROVÁ, R., LÁCOVÁ, M., EL-SHAAER, H.M., OLDEROVÁ, Ž.: Synthesis and antimycobacterial activity of some new 3-heterocyclic substituted chromones. Farmaco, 52, 1997, 251-253.

HAVEL, L., KONEČNÁ, H., SNÁŠELOVÁ, V., PROCHÁZKA, S., BLAŽKOVÁ, J.: Regeneration and peroxidases activity in cabbage tissue culture under the influence of benzolinon and auxins. Rost. Výr., 40, 1994, 783 - 791.

HENSELOVÁ, M., MACHLICOVÁ, A., BUJDOŠ, M.: Benzolinone - induced tolerance of Phytolacca dioica L. Plants to cadmium stress. Proceedings of $27^{\text {th }}$ International Symposium „Industrial Toxicology '07“ STU Bratislava, 2007, 174179.

CHANG, I.K., FOY, C.L.: Rapid growth responses of dwarf corn coleoptile sections to picloram. Pestic. Biochem. Physiol.,19, 1983, 203-209.

KLECOVÁ-ŠIMONOVÁ, E., HENSELOVÁ, M., MASAROVIČOVÁ, E., ZAHRADNÍK, P.: Resistance increasing of Vigna radiata and Brassica juncea plants to Cd-stress after application of benzothiazole derivative. Sborník z konference ,Vliv abiotických a biotických stresorů na vlastnosti rostlin 2008“. VÚRV Praha, 2008, 234-238. (In Slovak).

KLEŠTINEC, M., GAŠPAROVÁ, R., LÁCOVÁ, M.: in preparing

KOLLÁROVÁ, K., HENSELOVÁ, M., LIŠKOVÁ, D.: Effect of auxins and plant oligosaccharides on the root formation and elongation growth of mung bean hypocotyls. Plant Growth Reg., 46, 2005, 1-9.

KRÁL'OVÁ, K., MITTERHAUSZEROVÁ, L., HALGAŠ, J.: Effect of some benzothiazolium salts on chlorophyl production in Chlorella vulgaris. Biol. Plant., $36,1994,477-479$.

KRÁLOVÁ, K., ŠERŠEŇ, F., GAŠPAROVÁ, R., LÁCOVÁ, M.: Effect of 3-R ${ }^{2} \mathrm{CH}_{2}-$ 2-[2-(6- ${ }^{1}$-Chromon-3-yl)ethenyl]benzothiazolium halides on photosynthetic processes. Chem. Pap., 52, 1998, 776 - 779.

KRIEG, M., BILLITZ, J.: Structurally modified trimethyne thiacarbocyanine dyes. Effect of N-alkyl substituents on antineoplastic behavior. Mol. Biochem. Pharmacol., 51, 1996, 1461-1467.

LÁCOVÁ, M., STANKOVIČOVÁ, H., ODLEROVÁ, Ž.: Chromonyl-aminosalicylic acid derivatives as possible antimycobacterial agents. Farmaco, 50, 1995, 885-888.

MAGDOLEN, P., ZAHRADNÍK, P., FOLTÍNOVA, P.: Synthesis, antimicrobial testing and QSAR study of new 2-phenylethenylbenzothiazolium salts substituted by cyclic amines. Pharmazie, 55, 2000, 803-810.

MERRILL, G.B.: Eupatoriochromene and encecalin, plant-growth regulators from yellow starthistle (Centaurea solstitialis L). J. Chem. Ecol., 15, 1989, 2073-2087. 
MÜLLER, J.L.: Indole-3-butyric acid in plant growth and development. Plant Growth Reg., 32, 2000, 219-230.

NAWROT-MODRANKA, J., NAWROT, E., GRACZYK, J.: In vivo antitumor, in vivo antibacterial activity and alkylating properties of phosphorohydrazine derivatives of coumarin and chromone. Eur. J. Med. Chem., 41, 2006, 1301-1309.

ŠIMONOVÁ, E., HENSELOVÁ, M., ZAHRADNÍK, P.: Benzothiazole derivatives substituted in position 2 as biologically active substances with plant growth regulation activity. Plant Soil Environ., 51, 2005, 496-505.

SUTORIS, V., BAJČI, P., SEKERKA, V., HALGAŠ, J.: Benzothiazolium salts which increase sugar and chlorophyl contents in plants. Chem. Pap., 42, 1988, 249 - 261.

SUTORIS, V., GÁPLOVSKÝ, A., SEKERKA, V.: Benzothiazole compounds. xlvi. 3,4-disubstitued 2-benzothiazolinones with plant growth regulation activity. Chem. Pap., 47, 1993, 260-263.

WANG, S., TAKETA, S., ICHII, M., XU, L., XIA, K., ZHOU, X.: Lateral root formation in rice (Oryza sativa L.): Differential effects of indole-3-acetic acid and indole 3-butyric acid. Plant Growth Reg., 41, 2003, 41-47.

YORK, W.S., DARVILL, A.G., ALBERSHEIM, P.: Inhibition of 2,4dichlorophenoxyacetic acid-stimulated elongation of pea stem segments by a xyloglucan oligosaccharide. Plant Physiol., 75, 1984, 295-297. 